\title{
Population structure, diametric distribution and use of Commiphora leptopholoeos (Mart.) JB Gillett in arboreal Caatinga ${ }^{1}$
}

\author{
Walleska Pereira Medeiros ${ }^{2}$, Alessandro de Paula ${ }^{3 *}$ (D), \\ Patrícia Anjos Bittencourt Barreto-Garcia ${ }^{3}$,Odair Lacerda Lemos ${ }^{3}$
}

10.1590/0034-737X202269010009

\begin{abstract}
The objective of this work was to characterize the population structure, analyze the spatial distribution pattern and identify the potential use of the Commiphora leptopholoeos in the Contendas do Sincorá National Forest, BA. Thus, three disjoint transects of $40 \times 160 \mathrm{~m}$ were installed for the phytosociological study and spatial distribution and subdivided into 64 plots of $10 \times 10 \mathrm{~m}$, for which the density and frequency values of regenerating individuals $(\mathrm{dbh}<5$ $\mathrm{cm}$ ), and the density, frequency and basal area of arboreal size were calculated $(\mathrm{dbh} \geq 5 \mathrm{~cm})$. The spatial distribution pattern was calculated by the Morisita index, Payandeh's dispersion index and the Chi-squared test for the different populations. The diametric distribution was in the form of a reverse J-shaped, usually indicate full regeneration with constant seed production, germination and recruitment. The stems of the species were mostly healthy, but with a large tillering percentage and tortuosity below the commercial height, constituting characteristics which favor uses for firewood, stakes and poles. The spatial distribution pattern values of the species for tree size and regeneration point to an aggregate spatial distribution or to a tendency to aggregation.
\end{abstract}

Keywords: Contendas do Sincorá National Forest; natural regeneration; vitality class; stem quality; dispersion index.

\section{INTRODUCTION}

Commiphora lepthophloeos (Mart.) J.B. Gillet (Burseraceae) is one of the most representative species of the Caatinga biome, which it can be observed for its high density and importance values (Marangon et al., 2013; Carvalho, 2009; Silva \& Scariot, 2004).

It is popularly known as Imburana-de-cambão, Imburaninha or Imburana-de-Espinho. It presents deciduousness with heliophile, pioneer and xerophilic behavior. Its height varies between three and four meters as an adult, but its largest individuals can reach dimensions of approximately $12 \mathrm{~m}$ in height and $60 \mathrm{~cm}$ in diameter (Carvalho, 2009).

It has proven uses such as for animal feed, energy, medicine, handicrafts, landscaping, carpentry and construction. It provides pollen and nectar, in addition to harboring native bees in their hollow trunks, demonstrating a potential apiculture. In projects for the recovery of degraded areas and enrichment of capoeira (secondary forest) and devastated forests, it has been indicated for the first phase to act as an initial colonizer (Maia, 2012; Carvalho, 2009). It is worth mentioning that this species is not endemic to the caatinga and has a wide and discontinuous distribution throughout Brazil, also it being found in the Atlantic Forest and Cerrado biomes (Carvalho, 2009).

Despite the potentials already identified, the species needs more scientific investigation that allows its use to propose a management more appropriate to its characteristics. As an example, we can mention the fact that it has mostly non-profiled shafts, which it shows a wide possibility of more noble uses of its wood.

\footnotetext{
Submitted on September $1^{s t}, 2020$ and accepted on April 15 $5^{\text {th }}, 2021$.

${ }^{1}$ This work is part of the first author's Master Dissertation.

${ }^{2}$ Universidade Estadual do Sudoeste da Bahia, Programa de Pós-Graduação em Ciências Florestais, Vitória da Conquista, Bahia, Brazil. walleskap@hotmail.com

${ }_{3}^{3}$ Universidade Estadual do Sudoeste da Bahia, Departamento de Engenharia Agrícola e Solos, Vitória da Conquista, Bahia, Brazil. apaula@uesb.edu.br; patriciabarreto@uesb.edu.br; olemos@uesb.edu.br

*Corresponding author: apaula@uesb.edu.br
} 
The study of diametric distributions has several applications in forest science, as it can be used as an indicator of the growing stock (Machado et al., 2009), of the forest structure and in the distinction of forest types, in addition to providing subsidies for identifying the intensity of natural regeneration of the forest or species (Machado et al., 2010). For Orellana et al. (2014), the diameter distribution knowledge can be used to assess natural regeneration and define extraction/exploitation criteria, aiming toward sustainable management of the forest and individual species.

In addition to the diametric distribution, studies related to the spatial distribution have been essential in understanding the behavior of a given species and its environment in terms of landscape ecology and occupation forms (Gurevitch et al., 2009). Such studies facilitate understanding the influence on the forest structure, understanding colonization forms, propagule spread and ways of managing a particular species (Martins, 2009; Gurevitch et al., 2009).

C. leptopholoeos is a species which stands out in terms of its various uses in the Northeast region of Brazil. Despite being a species potentially used in several categories, scientific studies are still incipient as to its ecology. Scientific investigations point to problems regarding natural regeneration, showing that the wood supply of this species may be reduced in the future. It is worth noting that the species is allogamous (crosspollination) and it has zoocoria (avifauna) as its main dispersion syndrome (Carvalho, 2009). In this sense, Affonso et al. (2014) concluded that the species is not capable of forming a permanent seed bank in Caatinga soils, as germination is drastically reduced after 12 months of storage under natural or artificial conditions.

Thus, this study aimed to characterize the population structure, analyze the spatial distribution pattern and identify the potential use of the Commiphora leptopholoeos (Mart.) J.B. Gillett species in the Contendas do Sincorá National Forest, BA.

\section{MATERIAL AND METHODS}

The study was carried out in the Contendas do Sincorá National Forest which it has its headquarters located on the BA-026 highway, $\mathrm{km} 20$, in the municipality of Contendas do Sincorá, state of Bahia, Brazil. It is located at $13^{\circ} 55^{\prime} 21^{\prime \prime}$ South latitude and $41^{\circ} 06$ ' 57' West longitude and has an area of 11,034 hectares. It was created in 1999 as part of environmental compensation. Before its creation as a Conservation Unit, the property was used for coal mining which subsidized the activities of the Magnesita SA company from 1990 to 1994, and was later sold to the Siderúrgica Itaminas SA company, which operated until 1997, ceding the property after that period as a means of acquiring Forestry Recovery Credits (MMA, 2006).

The predominant vegetation formation in Contendas do Sincorá National Forest is the Caatinga tree species, according to IBGE (2012) classified as Forested SteppeSavanna. This formation subgroup is fundamentally structured in two strata: an upper one with a predominance of periodically deciduous nanophanerophytes and relatively dense by thick, carved and spiny or accented trunks and a lower grassy-woody layer, generally discontinuous and with little physiognomic expression.

The region's climate according to the Köeppen classification is warm. Irregular rains, low intensity, concentrated in the summer (BSwh). The rainiest period runs from November to April, with an annual rainfall range between 596 and $679 \mathrm{~mm}$, average temperature of $23^{\circ} \mathrm{C}$, and relative humidity of 20 to $40 \%$. According Barreto-Garcia et al. (2020), the soil is Ultisol (Soil Survey Staff, 2014).

Three disjointed transects of $40 \mathrm{~m} \times 160 \mathrm{~m}$ distant 260 $\mathrm{m}$ were installed for the phytosociological and spatial distribution studies, it being subdivided into 64 plots of $10 \times 10 \mathrm{~m}$ (Figure 1). Regenerating and arboreal individuals of the $C$. leptophloeos species were sampled in the plots.

Individuals with height greater than or equal to $0.5 \mathrm{~m}$ and dbh less than $5 \mathrm{~cm}$ were considered as natural regeneration according to a methodology adapted from the protocol of the Scientific Technical Committee of the Caatinga Forest Management Network (CTCRMFC, 2005). The individuals were qualified by height class, being: CI $=$ height from 0.5 to $1.0 \mathrm{~m}$; and $\mathrm{CII}=$ height above $1.0 \mathrm{~m}$ and $\mathrm{dbh}>5 \mathrm{~cm}$.

For arboreal size, all individuals who presented stems with $\mathrm{dbh} \geq 5.0 \mathrm{~cm}$ were considered and the following were recorded: the diameter at breast height (dbh) and the base diameter (BD) measured at ground level with caliper, the total height with electronic clinometer, the vitality class ( $\mathrm{H}=$ healthy; $\mathrm{S}=$ sick and $\mathrm{D}=$ dead $)$, stem quality $(1=$ totally straight, no defects, no bifurcations up to $2.50 \mathrm{~m}$; 2 $=$ slightly askew or with few defects, no bifurcations up to $2.50 \mathrm{~m}$; and $3=$ very crooked, with serious defects or with bifurcations up to $2.50 \mathrm{~m}$ ), and the canopy position ( $\mathrm{D}=$ Dominant, if it belongs to the top $10 \%$ of the trees in the plot; I = Intermediate, if located at the average height level of trees in the plot; or $\mathrm{O}=$ Oppressed, if located under crowns of the other trees in the plot) (CTCRMFC, 2005).

In order to evaluate the influence of the forest structure as a whole on C. leptophloeos, individuals with $\mathrm{dbh} \geq 5.0$ $\mathrm{cm}$ from other species present in the transects were also sampled.

Density and absolute frequency were the parameters used to analyze the horizontal natural regeneration structure of the specie (Souza \& Soares, 2013), in addition 
to the basal area. The vertical structure was analyzed according to the limits of each stratum, and the canopy position of each individual was calculated.

Regarding the diametric distribution of individuals of arboreal size, a class width of $5 \mathrm{~cm}$ was used according to the methodology suggested by Soares et al. (2007) for unequal stands.

Parametric assumptions were performed for statistical analysis, observing that the data distribution was devoid of normality (Shapiro-Wilk test) and homogeneity (Levene test). Although there was an attempt to parameterize the variables with the Box-Cox technique (Osborne, 2010), the data were not converted to the normal distribution. The Kruskal-Wallis non-parametric test was used in view of the lack of normality, followed by the Dunn test $(\alpha=0.05)$. In a complementary way, data on the number of individuals in the dominant stratum and natural regeneration were subjected to multivariate principal component analysis (PCA), to condense the multidimensional variation in a diagram, ordering the transects in the components according to their similarities (Ter Braak, 1986), and to evaluate the influence of the number of dominant individuals on the natural regeneration of the studied specie. All analyzes were performed using the Past 4.02 program (Hammer et al., 2001).
The Payandeh Dispersion Index (PDI) (Payandeh, 1970) and the Morisita Dispersion Index (MDI) (Morisita, 1962) were used to detect the spatial pattern. The PDI determines the degree of aggregation of the specie through the relationship between the variance in the number of individuals per plot, and the average number of individuals (Calegário et al., 1993). When PDI <1.0, there is no grouping or random; when 1.0 to 1.5 indicates a tendency to cluster, and when $\mathrm{PDI} \geq 1.5$, it indicates cluster or aggregation. Based on the MDI, values found less than 1.0 indicate uniform distribution, values equal to 1.0 indicate random distribution, and values greater than 1.0 indicate aggregate distribution.

The $x^{2}$ test (chi-squared) was used to statistically examine patterns in relation to randomness at $\mathrm{p}-1$ degrees of freedom. The $X^{2}$ value was verified with a significance of $5 \%$. The interpretation of the chi-squared value was based on the following criterion: if the calculated value is less than the tabulated value, the MDI does not differ significantly from 1 and the species will show a random distribution pattern. On the other hand, if the calculated chi-squared value is greater than the tabulated one, the species will tend to an aggregate distribution pattern (Brower \& Zar, 1997). The occurrence of individuals in the plots was compared with the Poisson distribution.

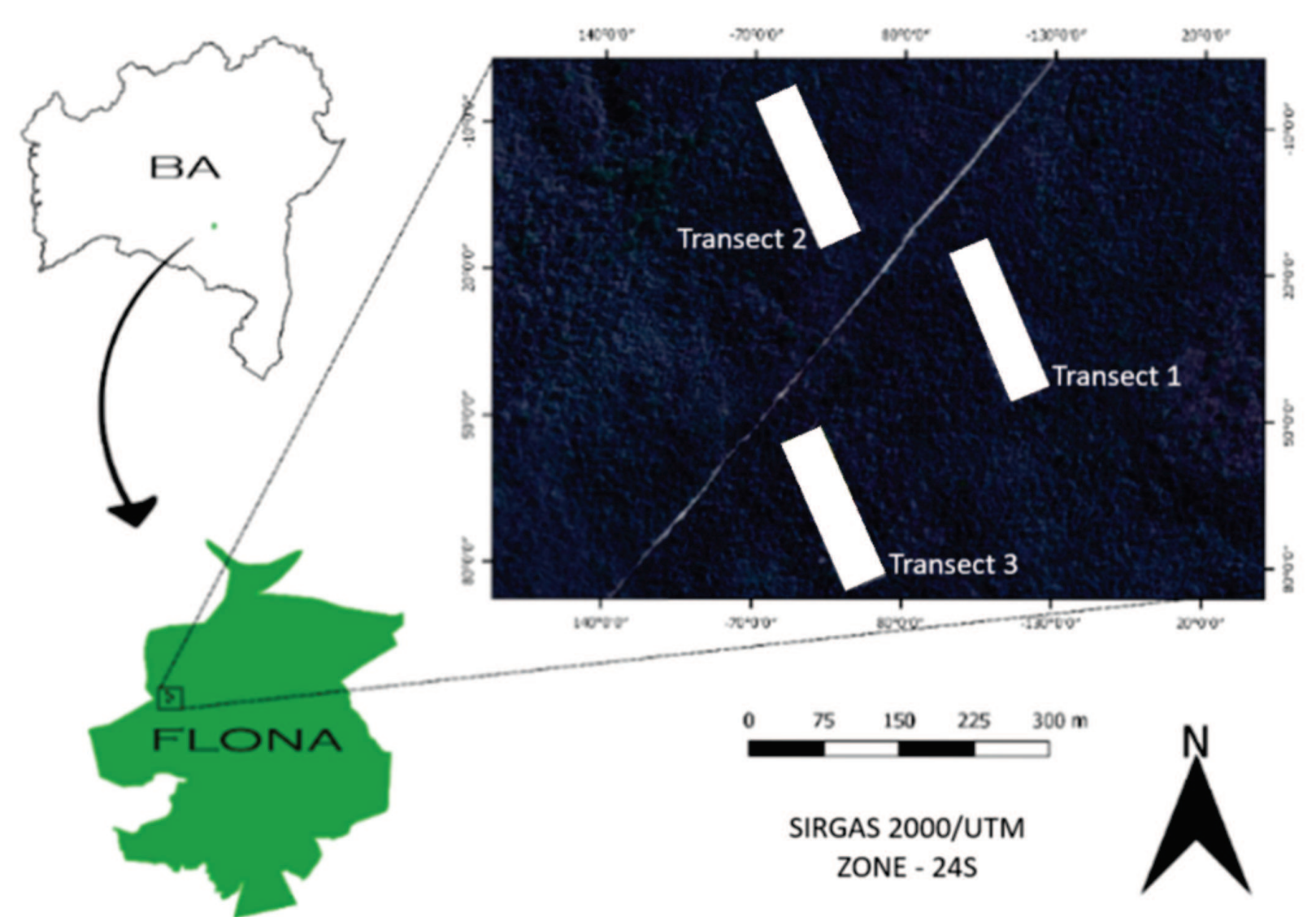

Figure 1: Location and distribution map of the experimental units, Contendas do Sincorá National Forest, Bahia. Author: Adriano Castro de Brito.

Rev. Ceres, Viçosa, v. 69, n.1, p. 062-069, jan/feb, 2022 


\section{RESULTS AND DISCUSSION}

\section{Natural regeneration structure}

A total of 102 individuals were sampled, distributed in the three transects. The highest values were found in transects I (43.1\%) and II (47.1\%), although with significant distinction in relation to transect III only in the CII and when considering the total number of individuals (Table 1). Statistical differences were observed in transects I and II when comparing the height classes in each of the transects, and the number of individuals was higher in CII (Table 1).

Additionally, data on the number of individuals explained $94 \%$ of the variation between treatments when submitted to PCA using two components (Figure 2). It is possible to verify a similar natural regeneration pattern in

Table 1: Number of regenerating individuals of the Commiphora leptophloeos (Mart.) J.B. Gillett in three transects in the Contendas do Sincorá National Forest - BA, Brazil, 2017, where: $\mathrm{CI}=$ height from 0.5 to $1.0 \mathrm{~m}$; $\mathrm{CII}=$ height above $1.0 \mathrm{~m}$ and dbh $>5 \mathrm{~cm}$; and $\mathrm{NI}=$ total number of individuals. Means followed by the same capital letter in the column and lower case in the line do not differ by Dunn's test at $5 \%$ probability

\begin{tabular}{lccc}
\hline Transect & CI & CII & NI \\
\hline I & $1 \mathrm{bA}$ & $43 \mathrm{aA}$ & $44 \mathrm{~A}$ \\
II & $2 \mathrm{bA}$ & $46 \mathrm{aA}$ & $48 \mathrm{~A}$ \\
III & $1 \mathrm{aA}$ & $9 \mathrm{aB}$ & $10 \mathrm{~B}$ \\
\hline Average & 1.3 & 32.7 & 34.0 \\
\hline
\end{tabular}

the three transects. However, it is noticed that the number of dominant individuals showed a different behavior among transect III and transects I and II. It was observed that the natural regeneration of transects I and II was negatively influenced by the number of dominant individuals, it being different from what occurred for transect III.

The average number of individuals sampled in this study was high when compared to other studies (Table 1). Farias et al. (2016), in Serra Talhada (PE), found 11 regenerating $C$. leptophloeos individuals in a study on the physiognomy and structure of the Caatinga vegetation in different environments.

Alves et al. (2010) and Alves Jr. et al. (2013) reported that the specie has establishment problems due to low regeneration values. However, the result found was different, as well as that by Farias et al. (2016) in which $C$. leptophloeos was among the most abundant species.

The predominance of individuals in the CII (Table 1) is attributed to the amplitude of the class. Souza et al. (2016) obtained the same result in a study of Caatinga area.

\section{Structure of arboreal individuals}

The total number of individuals from Transect I $(57.8 \%)$ differed statistically from Transects II (20.8\%) and III $(21.4 \%)$. When we observed the vertical distribution, it is clear that this pattern is only repeated for individuals in the intermediate stratum. In relation to the oppressed class, the significance was only verified in transect III. Transect

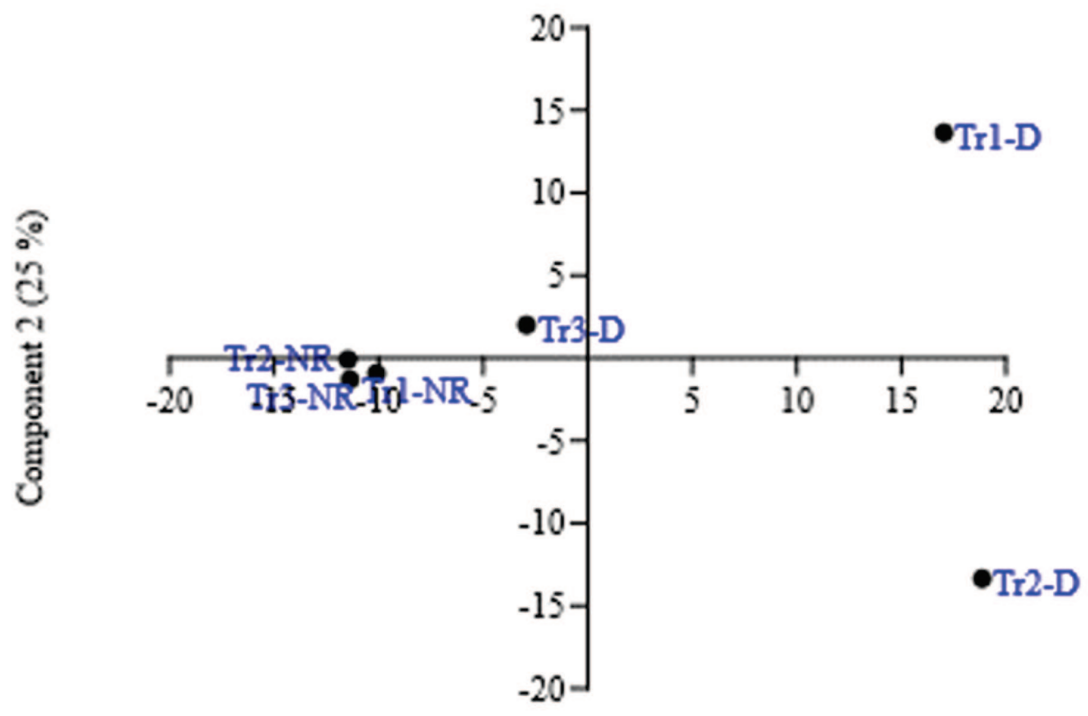

Component $1(69 \%)$

Figure 2: Principal Component Analysis relating the number of canopy individuals in the forest with the natural regeneration of Commiphora leptophloeos (Mart.) JB Gillett in Transect III, in the Contendas do Sincorá National Forest - BA, Brazil, 2017, in which: $\operatorname{Tr} 1-\mathrm{D}=$ number of individuals from the dominant stratum in transect 1 ; $\operatorname{Tr} 2-\mathrm{D}=$ number of individuals from the dominant stratum in transect 2; Tr3-D = number of individuals from the dominant stratum in transect 3; Tr1-NR = number of individuals from natural regeneration in transect 1 ; $\operatorname{Tr} 2-\mathrm{NR}=$ number of individuals from natural regeneration in transect 2 ; and $\operatorname{Tr} 3-\mathrm{NR}=$ number of individuals from natural regeneration in the transect 3. 
I also differed from transects II and III for the basal area (Table 2).

Water availability has been identified as one of the main factors affecting plant communities in areas subjected to strong climatic seasonality (Trejo \& Dirzo, 2002; Segura et al., 2003), as occurs in vegetation environments in Caatinga (Andrade et al., 2009).

Regarding the canopy position, the pattern found in this study differs from that found by Souza et al. (2016) with a Caatinga fragment. They observed that the oppressed class had a greater number of individuals with a percentage of $65.17 \%$ of the stems, the intermediate class had $19.84 \%$ of the stems, and the dominant class had $14.99 \%$ of the stems.

In a study carried out in the same location, Lima \& Lima (1998) found a much higher value than that of the present study $\left(4.717 \mathrm{~m}^{2} \mathrm{ha}^{-1}\right)$. It is worth mentioning that it was still called Fazenda Extrema-Lapinha in this period, and it was used to extract wood for charcoal production through a Management Plan.

\section{Diameter class}

The distribution of individuals by diameter classes showed a high concentration of stems in the smaller diameter classes. The largest diameter observed was 51.6 $\mathrm{cm}$. The distribution of individuals by diameter classes followed the reverse J-shaped trend, with classes 7.5 and 12.5 being the most frequent, with $29.7 \%$ and $39.1 \%$, respectively (Figure 3).

The distribution of the total number of individuals by diameter class following the reverse J-shaped pattern indicated that the specie is in full regeneration with constant seed production, germination and recruitment (Dalla Lana et al., 2013). Other studies carried out in the Caatinga biome also found a greater concentration of individuals in the smallest diameter classes (Almeida Neto et al., 2009; Dantas et al., 2010; Marangon et al., 2013; Farias et al., 2016). This pattern confirms what has been reported in native forests in general, and tropical forests in particular are generally designated as having the reverse J-shaped, indicating a decreasing number of trees as the diameter increases (Lima \& Leão, 2013).

\section{Qualitative analysis}

Most of the stems were classified as healthy in both the general average and by transect, which corresponded to $87 \%$ of the individuals (Table 3 ). The number of diseased stems evaluated was 24 , making a total of $12.5 \%$ of the individuals.

The individuals sampled in this study were mostly healthy. In studying a Caatinga fragment, Souza et al. (2016) registered $71.73 \%$ of healthy stems. This indicates that the specie exhibits the standard behavior of a community in the Caatinga biome, meaning there are many healthy individuals and low mortality.

In the analysis of stem quality, it was observed that most of the stems were classified as very crooked with serious defects (hollow, cracked, rotten) or with bifurcations, making a total of $62.5 \%$ (Table 4). Only $8.3 \%$ of the individuals had straight stems and no bifurcations.

A low quality of $C$. leptopholoeos individuals was also observed by Souza et al. (2016), who found $71.73 \%$ of the healthy stems and $89.40 \%$ classified as class III stem quality in the Caatinga area, considering this pattern as being typical of Caatinga vegetation. The results obtained show low potential for using the specie for purposes such as sawn wood and furniture.

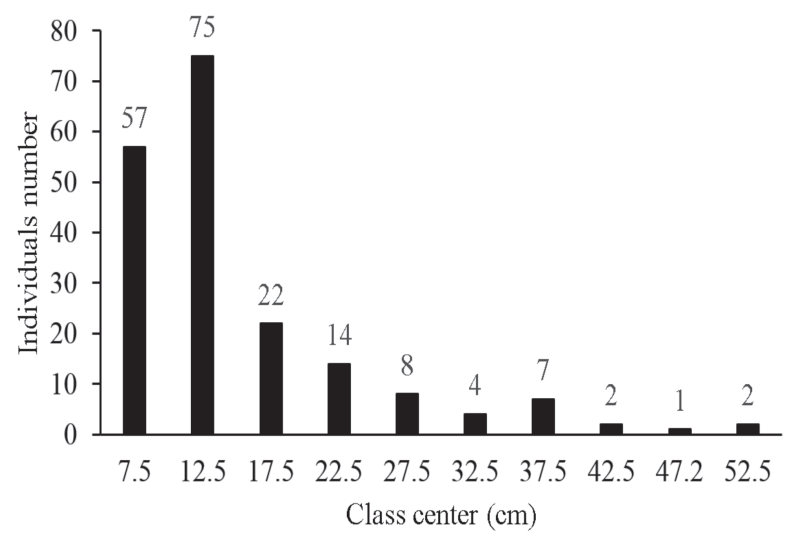

Figure 3: Distribution Commiphora leptophloeos (Mart.) J.B. Gillett individuals in diameter classes of $5 \mathrm{~cm}$ in the Contendas National Forest of Sincorá - BA, Brazil, 2017.

Table 2: Number of the arboreal individuals, canopy position and basal area (BA) of Commiphora leptophloeos (Mart.) J.B. Gillett in three transects in the Contendas do Sincorá National Forest - BA, Brazil, 2017, where: NI = total number of individuals, D = dominant; $\mathrm{I}=$ intermediate; and $\mathrm{O}=$ oppressed. Means followed by the same capital letter in the column and lower case in the line do not differ by Dunn's test at $5 \%$ probability

\begin{tabular}{lccccc}
\hline Transect & NI & D & I & O & BA $\left(\mathbf{m}^{2} / \mathbf{h a}^{-1}\right)$ \\
\hline I & $111 \mathrm{~A}$ & $14 \mathrm{cA}$ & $51 \mathrm{aA}$ & $46 \mathrm{bA}$ & $1.8916 \mathrm{~A}$ \\
II & $40 \mathrm{~B}$ & $3 \mathrm{bA}$ & $11 \mathrm{abB}$ & $26 \mathrm{aA}$ & $0.8819 \mathrm{~B}$ \\
III & $41 \mathrm{~B}$ & $12 \mathrm{abA}$ & $26 \mathrm{aB}$ & $3 \mathrm{bB}$ & $1.1816 \mathrm{~B}$ \\
\hline Average & 64 & 9.7 & 29.3 & 25.0 & 1.3184 \\
\hline
\end{tabular}

Rev. Ceres, Viçosa, v. 69, n.1, p. 062-069, jan/feb, 2022 


\section{Spatial pattern}

The PDI showed values greater than 1.0 in all transects, indicating an aggregate spatial distribution or with a tendency to aggregate the specie (Table 5). In addition, the MDI indicated an aggregate distribution pattern for all transects for both tree size and for regeneration, with values ranging from 1.42 to 4.60 .

The $\chi^{2}$ values calculated for both tree size and for regeneration in all transects were higher than the $\chi^{2}$ tabulated value, resulting in an aggregate distribution.

For arboreal size, most plots in all transects had between one and three individuals. The same pattern was found for regeneration where most plots had one or two individuals (Table 6).

Table 3: Vitality classes and canopy position of Commiphora leptophloeos (Mart.) J.B. Gillett in the Contendas do Sincorá National Forest - BA, Brazil, 2017

\begin{tabular}{lcrcc}
\hline \multirow{2}{*}{ Transect } & \multicolumn{4}{c}{ Vitality } \\
\cline { 2 - 5 } & H & S & D & Total \\
\hline I & 93 & 17 & 1 & 111 \\
II & 38 & 2 & - & 40 \\
III & 36 & 5 & - & 41 \\
\hline Total & 167 & 24 & 1 & 192 \\
\hline Total (\%) & 87.0 & 12.5 & 0.5 & 100 \\
\hline
\end{tabular}

In which: Vitality $-\mathrm{H}=$ Healthy stem; $\mathrm{S}=$ Sick stem; D = Dead stem.

Table 4: Stem quality of Commiphora leptophloeos (Mart.) J.B. Gillett in the Contendas do Sincorá National Forest - BA, Brazil, 2017

\begin{tabular}{lcccc}
\hline \multirow{2}{*}{ Transect } & \multicolumn{5}{c}{ Stem quality } \\
\cline { 2 - 5 } & C1 & C2 & C3 & Total \\
\hline I & 4 & 34 & 73 & 111 \\
II & 1 & 13 & 26 & 40 \\
III & 11 & 9 & 21 & 41 \\
\hline Total & 16 & 56 & 120 & 192 \\
\hline Total $(\%)$ & 8.33 & 29.17 & 62.5 & 100
\end{tabular}

In which: $\mathrm{C} 1$ = totally straight, no defects, no bifurcations up to $2.50 \mathrm{~m} ; \mathrm{C} 2$ = slightly crooked or with few defects, no bifurcations up to $2.50 \mathrm{~m}$; and $\mathrm{C} 3=$ very crooked, with serious defects or bifurcations up to $2.50 \mathrm{~mm}$.
It was possible to verify the existence of more plots with a larger number of individuals than expected in the tree size (Table 6), which it demonstrated an aggregate pattern. This pattern occurred in plots with five, six, nine and 11 individuals in Transect I, while it occurred in plots with four individuals in Transect II, and in plots with four and five individuals in Transect III.

The "aggregate" type pattern observed by PDI, MDI and $\chi^{2}$ for the tree size of the specie was also found by Santana et al. (2016). In studying the tree size of this species in a Caatinga area, Marangon et al. (2013) found that it had a "tendency to aggregate". Bruzinga et al. (2013) reported that the aggregate distribution pattern may indicate that the species has a limited dispersion in relation to the propagule source or is demanding under specific microenvironmental conditions.

It is worth highlighting the fact that $C$. leptophloeos has wide and discontinuous dispersion (Carvalho, 2009), and the aggregation can be considered common in species with this characteristic. This specie is reputed as a pioneer and indicated for the first phase of recovery of degraded areas (Carvalho, 2009). According to Nasi (1993), species which inhabit altered locations tend to aggregate. The author still characterizes these species as aggressive, adapted to varied ecological conditions which applies to the species studied. Another important characteristic is its zoochoric dispersion, mainly by avifauna (Carvalho, 2009), which according to Antonini $\&$ Nunes-Freitas (2004), generate an aggregate spatial distribution pattern.

Dispersing animals have a great influence on the spatial patterns of seeds and consequently of seedlings (Crawley, 1986). As an example, we can mention the behavior of rodents and birds, which feed by taking fruits to their shelters and natural perches, respectively (Pottker et al., 2016). The degree of influence of seed dispersal also depends on the way the mother plants are distributed (Crawley, 1986).

The presence of clearings is a factor which favors aggregation of young individuals due to the increase in light intensity (Capretz et al., 2012). This fact mainly has an influence on the species under study as it shows

Table 5: Spatial distribution pattern of the Commiphora leptopholoeos (Mart.) J.B. Gillett species in a stand at Contendas do Sincorá National Forest - BA, 2017

\begin{tabular}{|c|c|c|c|c|c|c|c|c|}
\hline \multirow{2}{*}{ Transect } & \multicolumn{4}{|c|}{ Arboreal size } & \multicolumn{4}{|c|}{ Regeneration } \\
\hline & $\mathbf{N}$ & PDI & MDI & $x^{2}$ & $\mathbf{N}$ & PDI & MDI & $x^{2}$ \\
\hline I & 111 & 2.66 & 1.95 & 167.49 & 44 & 1.29 & 1.42 & 81.09 \\
\hline II & 40 & 1.45 & 1.72 & 91.20 & 48 & 3.68 & 4.60 & 232.00 \\
\hline III & 41 & 1.90 & 2.42 & 119.78 & 10 & 1.47 & 4.27 & 92.40 \\
\hline
\end{tabular}

In which: N: number of individuals; PDI: Payandeh Dispersion Index; MDI: Morisita Index; $x^{2}$ : calculated chi-squared value. 
Table 6: Percentage of plots per number of individuals of Commiphora leptophloeos (Mart.) J.B. Gillett at a stand in Contendas do Sincorá National Forest - BA, 2017

\begin{tabular}{|c|c|c|c|c|c|c|c|c|c|c|c|c|}
\hline \multirow{3}{*}{ NInd } & \multicolumn{4}{|c|}{$\begin{array}{l}\text { Transect I } \\
\text { Frequency }\end{array}$} & \multicolumn{4}{|c|}{$\begin{array}{l}\text { Transect II } \\
\text { Frequency }\end{array}$} & \multicolumn{4}{|c|}{$\begin{array}{l}\text { Transect III } \\
\text { Frequency }\end{array}$} \\
\hline & \multicolumn{2}{|c|}{ AS } & \multicolumn{2}{|c|}{$\mathbf{R}$} & \multicolumn{2}{|c|}{ AS } & \multicolumn{2}{|c|}{$\mathbf{R}$} & \multicolumn{2}{|c|}{ AS } & \multicolumn{2}{|c|}{$\mathbf{R}$} \\
\hline & OF & EF & OF & EF & OF & EF & OF & EF & OF & $\mathbf{E F}$ & OF & $\mathbf{E F}$ \\
\hline 0 & 28.13 & 17.65 & 89.06 & 50.28 & 59.38 & 53.53 & 67.19 & 47.24 & 60.94 & 52.70 & 59.38 & 85.53 \\
\hline 1 & 34.38 & 30.61 & 6.25 & 34.57 & 26.56 & 33.45 & 18.75 & 35.43 & 26.56 & 33.76 & 26.56 & 13.36 \\
\hline 2 & 17.19 & 26.55 & 4.69 & 11.88 & 9.38 & 10.45 & 3.13 & 13.29 & 7.81 & 10.81 & 9.38 & 1.04 \\
\hline 3 & 6.25 & 15.35 & 0.00 & 2.72 & 1.56 & 2.18 & 7.81 & 3.32 & 0.00 & 2.31 & 1.56 & 0.05 \\
\hline 4 & 3.13 & 6.65 & 0.00 & 0.47 & 3.13 & 0.34 & 0.00 & 0.62 & 1.56 & 0.37 & 3.13 & 0.00 \\
\hline 5 & 4.69 & 2.31 & 0.00 & 0.06 & 0.00 & 0.04 & 0.00 & 0.09 & 3.13 & 0.05 & & \\
\hline 6 & 3.13 & 0.67 & 0.00 & 0.01 & & & 0.00 & 0.01 & 0.00 & 0.01 & & \\
\hline 7 & 0.00 & 0.17 & & & & & 0.00 & 0.00 & & & & \\
\hline 8 & 0.00 & 0.04 & & & & & 1.56 & 0.00 & & & & \\
\hline 9 & 1.56 & 0.01 & & & & & 1.56 & 0.00 & & & & \\
\hline 10 & 0.00 & 0.00 & & & & & & & & & & \\
\hline 11 & 1.56 & 0.00 & & & & & & & & & & \\
\hline
\end{tabular}

In which: NInd - number of individuals; AS - arboreal size; R - regeneration; OF - observed frequency; EF - expected frequency.

heliophile behavior. The different levels of light intensity provided by the canopy and clearings can increase the survival of seedlings in specific places.

\section{CONCLUSIONS}

The natural regeneration behavior was not impacted by shading.

The diametric distribution was in the reverse J-shaped form, indicating that the species is in full regeneration with constant seed production, germination and recruitment.

The stems of the specie were mostly healthy, but with a high percentage of tillering and tortuosity below the commercial height, constituting characteristics which favor its uses as firewood, stakes and poles.

The spatial distribution pattern values of the specie for tree size and regeneration point to an aggregate spatial distribution or with a tendency to aggregation. This confirms the characteristic of the specie to form clusters.

\section{ACKNOWLEDGEMENTS, FINANCIAL SUPPORT AND FULLDISCLOSURE}

To the Fundação de Amparo à Pesquisa do Estado da Bahia - FAPESB, for granting the Master's scholarship to the first author. To Instituto Chico Mendes de Conservação da Biodiversidade - ICMBio for permission to develop this research in the Floresta Nacional Contendas do Sincorá, and to the Laboratório de Ecologia e Proteção Florestal of the Universidade Estadual do Sudoeste da Bahia-UESB.

\section{REFERENCES}

Affonso IB, Siqueira Filho JÁ \& Meiado MV (2014) A permanência das sementes de Commiphora leptophloeos (Mart.) J.B. Gillet (Burseraceae) no solo da Caatinga favorece sua germinação? Informativo ABRATES, 24:35-38.

Almeida Neto JX, Andrade AP, Lacerda AV, Félix LP \& Bruno RLA (2009) Composição Florística, Estrutura e Análise Populacional do Feijão-Bravo (Capparis flexuosa L.) no Semiárido Paraibano, Brasil. Revista Caatinga, 22:187-194.

Alves Jr. FT, Ferreira RLC, Silva JAA, Marangon LC \& Cespedes GHG (2013) Regeneração natural de uma área de Caatinga no sertão pernambucano, Nordeste do Brasil. Cerne, 19:229-235.

Alves LS, Holanda AC, Wanderley JAC, Sousa JS \& Almeida PG (2010) Regeneração natural em uma área de Caatinga situada no município de Pombal - PB, Brasil. Revista Verde de Agroecologia e Desenvolvimento Sustentável, 5:152-168.

Andrade MVM, Andrade AP, Silva DS, Bruno RLA \& Guedes DS (2009) Levantamento florístico e estrutura fitossociológica do estrato herbáceo e subarbustivo em áreas de Caatinga no Cariri paraibano. Revista Caatinga, 22:229-237.

Antonini RD \& Nunes-Freitas AF (2004) Estrutura populacional e distribuição espacial de Miconia prasina DC. (Melastomataceae) em duas áreas de Floresta Atlântica na Ilha Grande, RJ, Sudeste do Brasil. Acta Botanica Brasilica, 18:671-676.

Barreto-Garcia PAB, Batista SGM, Gama-Rodrigues EF, Paula A \& Batista WCA (2020) Short-term effects of forest management on soil microbial biomass and activity in caatinga dry forest, Brazil. Forest Ecology and Management, 481:118790.

Brower JE \& Zar JH (1997) Field and laboratory methods for general ecology. $2^{\text {nd }}$ ed. Iowa, Northern Illinois University. 226p.

Bruzinga JS, Oliveira MLR, Machado ELM, Leite HG, Pereira IM \& Nogueira GS (2013) Distribuição espacial de indivíduos adultos de pequi. Scientia Forestalis, 41:249-256.

Calegário N, Souza AL, Marangon LC \& Silva AF (1993) Estimativas dos parâmetros de distribuição e de associação de espécies vegetais nativas regeneradas no sub-bosque de Eucalyptus, no município de Belo Oriente/MG. Revista Árvore, 17:146-161. 
Capretz RL, Batista JLF, Sotomayor JFM, Cunha CR, Nicoletti MF \& Rodrigues RR (2012) Padrão espacial de quatro formações florestais do estado de São Paulo, através da função K de Ripley. Ciência Florestal, 22:551-565.

Carvalho PER (2009) Imburana-de-Espinho - Commiphora leptophloeos. Colombo, Embrapa Florestas. 8p. (Technical Bulletin, 228).

Crawley MJ (1986) Plant Ecology. Oxford, Blackwell Scientific Publications. 496p.

CTCRMFC - Comitê Técnico Científico da Rede de Manejo Florestal da Caatinga (2005) Rede de manejo florestal da Caatinga: protocolo de medições de parcelas permanentes/Comitê Técnico Científico. Recife, Associação Plantas do Nordeste. 21p.

Dalla Lana M, Brandão CFLS, Péllico Neto S, Marangon LC \& Retslaff FAS (2013) Distribuição diamétrica de Escheweilera ovata em um fragmento de Floresta Ombrófila Densa - Igarassu, PE. Floresta, 43:59-68.

Dantas JG, Holanda AC, Souto LS, Japiassu A \& Holanda EM (2010) Estrutura do componente arbustivo/arbóreo de uma área de Caatinga situada no município de Pombal-PB. Revista Verde, $5: 134-142$.

Farias SGG, Rodal MJN, Melo L, Silva MAM \& Lima ALA (2016) Fisionomia e estrutura de vegetação de Caatinga em diferentes ambientes em Serra Talhada - Pernambuco. Ciência Florestal, $26: 435-448$.

Gurevitch J, Scheiner SM \& Fox GA (2009) Ecologia Vegetal. $2^{\text {nd }}$ ed. Porto Alegre, Artmed. 574p.

Hammer $\varnothing$, Harper DAT \& Ryan PD (2001) PAST: Paleontological Statistics software package for education and data analysis. Paleontologia Eletronica, 4:9.

IBGE - Instituto Brasileiro de Geografia e Estatística (2012) Manual Técnico da Vegetação Brasileira. $2^{\text {nd }}$ ed. Rio de Janeiro, Instituto Brasileiro de Meio Ambiente dos Recursos Naturais Renováveis. 271p.

Lima JPC \& Leão JRA (2013) Dinâmica de Crescimento e Distribuição Diamétrica de Fragmentos de Florestas Nativa e Plantada na Amazônia Sul Ocidental. Floresta e Ambiente, 20:70-79.

Lima PCF \& Lima JLS (1998) Composição florística e fitossociologia de uma área de Caatinga em Contendas do Sincorá, Bahia, microrregião homogênea da chapada diamantina. Revista Acta Botânica Brasileira, 12:441-450.

Machado SA, Augustynczik ALD, Nascimento RGM, Figura MA, Silva LCR, Miguel EP \& Teo SJ (2009) Distribuição diamétrica de Araucaria angustifolia (Bert.) O. Ktze. em um fragmento de Floresta Ombrófila Mista. Scientia Agraria, 10:103-110.

Machado SA, Santos AAP, Nascimento RGM, Augustynczik ALD \& Zami NT (2010) Modelagem da distribuição diamétrica de quatro espécies de Lauraceae em um fragmento de Floresta Ombrófila Mista. Revista Ciências Exatas e Naturais, 12:91105 .

Maia GN (2012) Caatinga: Árvores e arbustos e suas utilidades. $2^{\text {nd }}$ ed. Fortaleza, Printicolor Gráfica e Editores. 413p.
Marangon GP, Ferreira RLC, Silva JAL, Lira DFS, Silva EA \& Loureiro GH (2013) Estrutura e padrão espacial da vegetação em uma área de Caatinga. Floresta, 43:83-92.

Martins SV (2009) Ecologia de florestas tropicais do Brasil. Viçosa, Universidade Federal de Viçosa. 261p.

MMA - Ministério do Meio Ambiente (2006) Plano de Manejo Floresta Nacional Contendas do Sincorá. Brasília, Instituto Brasileiro de Meio Ambiente dos Recursos Naturais Renováveis. $132 \mathrm{p}$.

Morisita M (1962) Id-index, a measure of dispersion of individuals. Researches on Population Ecology, 4:1-7.

Nasi R (1993) Analysis of the spatial structure of a rattan population in a mixed dipterocarp forest of Sabah (Malaysia). Acta Oecologica, 34:73-85.

Orellana E, Figueiredo Filho A, Péllico Neto S \& Dias AN (2014) Modelagem da distribuição diamétrica de espécies florestais em um fragmento de Floresta Ombrófila Mista. Revista Árvore, 38:297-308.

Osborne J (2010) Improving your data transformations Applying the Box-Cox transformation. Practical Assessment, Research, and Evaluation, 15:1-9.

Payandeh B (1970) Comparison of method for assessing spatial distribution of trees. Forest Science, 16:312-317.

Pottker GS, Oliveira Filho PC, Figueiredo Filho A \& Dalmaso CA (2016) Padrão espacial de espécies florestais estudo de caso com Ocotea odorifera (Vell.) Rohwer. Ciência Florestal, 26:1097-1106.

Santana JAS, Santana Jr. JAS, Barreto WS \& Ferreira ATS (2016) Estrutura e distribuição espacial da vegetação da Caatinga na Estação Ecológica do Seridó, RN. Pesquisa Florestal Brasileira, 36:355-361.

Segura G, Balvanera P, Durán E \& Pérez A (2003) Tree community structure and stem mortality along a water availability gradient in a Mexican tropical dry forest. Plant Ecology, 169:259-271.

Silva LÁD \& Scariot A (2004) Comunidade arbórea de uma floresta estacional decídua sobre afloramento calcário na bacia do rio Paraná. Revista Árvore, 28:61-67.

Soil Survey Staff (2014) Keys to Soil Taxonomy. 12 $2^{\text {th }}$ ed. Washington, USDA-Natural Resources Conservation Service. 372p.

Soares CPB, Paula Neto F \& Souza AL (2007) Dendrometria e Inventário florestal. Viçosa, Editora UFV. 276p.

Souza AL \& Soares CPB (2013) Florestas nativas: estrutura, dinâmica e manejo. Viçosa, Editora UFV. 322p.

Souza PF, Silva JA, Lucena DS, Santos WS, Henriques IGN, Lucena MFA \& Souza AD (2016) Estudos fitossociológicos e dendrométricos em um fragmento de Caatinga, São José de Espinharas - PB. Ciência Florestal, 26:1317-1330.

Ter Braak CJF (1986) Canonical correspondence analysis: A new eingvector technique for multivariate direct gradiente analysis. Ecology, 67:1167-1179.

Trejo I \& Dirzo R (2002) Floristic diversity of Mexican seasonally dry tropical forests. Biodiversity Conservation, 11:2048-2063. 